\title{
Integrating local and expert knowledge using participatory mapping and GIS to implement integrated forest management options in Akok, Cameroon
}

\author{
by V. Robiglio ${ }^{1,2,3}$ and W.A. Mala ${ }^{4}$
}

\begin{abstract}
A spatially explicit understanding of local knowledge about land use and tenure is fundamental to developing and assessing sustainable management options for tropical forests in Central Africa. This paper presents a case study in the Humid Forest Zone of Cameroon to demonstrate the effectiveness of integrating participatory rural appraisal techniques with remote sensing and vegetation mapping in a geographic information system (GIS) environment. The full integration of biophysical and socio-cultural patterns within a GIS can identify spatial units important for ecosystem management and relate social institutions to land units across a variety of scales.
\end{abstract}

Key words: landscape, forest-agriculture interface, tropical forest management, land tenure, participatory mapping, local knowledge

\section{RÉSUMÉ}

La compréhension explicite au niveau spatial des connaissances locales de l'utilisation et de la tenure du territoire est essentielle pour élaborer et évaluer les options d'aménagement durable des forêts tropicales de l'Afrique centrale. Cet article présente une étude de cas tiré de la région des forêts humides du Cameroun dans le but de démontrer l'efficacité de l'intégration des techniques d'évaluation de la participation rurale au moyen de la télédétection et de la cartographie de la végétation au sein d'un système d'information géographique (SIG). L'intégration complète des modes biophysiques et socio-culturels au sein du SIG peut identifier les unités spatiales importantes au niveau de l'aménagement écosystémique et relier les institutions sociales aux unités territoriales selon une variété d'échelles.

Mots clés : paysage, interface forêt-agriculture, aménagement des forêts tropicales, tenure du territoire, cartographie participative, connaissances locales

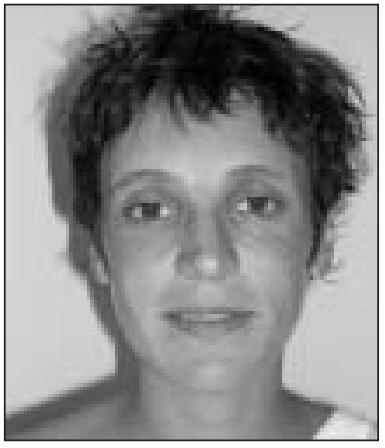

V. Robiglio

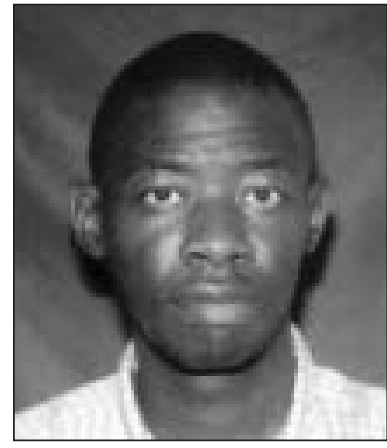

W.A. Mala

\footnotetext{
${ }^{1}$ School of Agricultural and Forestry Sciences, University of Wales, Bangor, UK.

${ }^{2}$ International Institute for Tropical Agriculture, Humid Forest Ecoregional, Centre 2008 B.P. (Messa) Yaoundé, Cameroon.

${ }^{3}$ Corresponding author. Present address: IITA Cameroon, c/o Lambourn, 26 Dingwall Road, Croydon CR 3EE, UK. E-mail: v.robiglio@cgiar.org

${ }^{4}$ Centre for International Forestry Research, 2008 B.P. (Messa) Yaoundé, Cameroon.
}

\section{Introduction}

Forests in the Humid Forest Zone (HFZ) of Cameroon are under increasing pressure from logging and small-scale farming. Since the establishment of permanent villages along roads built by the colonial government, agricultural fronts have expanded into the forest (Mertens and Lambin 1997, 2000; Ndoye and Kaimowitz 2000; Geist and Lambin 2002). Remote sensing analyses have identified that the penetration of agricultural corridors into the original forest matrix has caused deforestation at an estimated rate of $0.6-0.9 \%$ per annum (La Porte et al. 1995, FAO 2001). This has precipitated two key forms of conflict: competition for land between forest and agriculture use at the local scale, and between forest conservation and economic development at the landscape scale.

Although there have been many studies on farming and land tenure systems in the HFZ (Diaw 1997, Nounamo and Yemefack 2001, Gockowski et al. 2002), landscape-level analyses of natural resource management encompassing both agricultural and forest components are noticeably absent. Also, little is known about the social construction of the land use patterns that emerge from the aggregation of land use decisions taken by individual small-scale farmers. conditioned by local social institutions, operating at a variety of scales.

Understanding the spatial extent of production systems, the spatial structure of tenure and the scales at which land management operates is fundamental to developing and assessing the 
sustainable use of forest resources in Central Africa. This assertion makes it important to map the local understanding of agricultural and forest land uses and management and attempt to reconcile these with the spatial information available for large areas of the region (Coté 1992) that is the basis for decisions concerning land use policy and planning.

The objective of this research was to develop a geographically consistent representation of natural resource management across the landscape using a combination of participatory methods and a geographic information system (GIS). The project also comprised several technical objectives: 1) to identify the territory of the villages by micro-ecological zone and the associated principal natural resources, 2) to identify the spatial dimensions of resource management and land use, 3 ) to identify the social rules and social levels of land-use decision-making, and 4) to integrate this information in a database for quantitative spatial modelling using GIS.

Participatory mapping and GIS were combined in an effort to define and map land management units that are subject to land use decisions together with the reach of social institutions that condition them. It is anticipated that the quantitative spatial analysis of land use and access to resources will help clarify the relationships between the social groups that affect natural resources management decisions in the case study region.

\section{Background: Farming System and Access to Forest Land in Southern Cameroon}

The livelihood system of small-scale farmers in the HFZ is based on shifting cultivation associated with cocoa, the collection of various products from the forest, including non timber forest products (NTFPs), hunting, fishing, and small-scale logging for domestic use (Russell 1993, Nounamo and Yemefack 2001, Gockowski et al. 2002). While shifting cultivation is recognized as a threat to forest cover, the importance of forest-based hunting and gathering to peoples' livelihoods suggests a complementarity between forest management and agriculture. The central importance of the forest to local farmers is evident in the traditional social representation of terrestrial space, which defines the forest as part of the agricultural land (Diaw 1997).

In Cameroon, access to forest resources is officially governed by the Forestry Law of 1994. The Forestry Law of 1994 is based on a sharp separation of specialized productive spaces, in contrast with the long-established customary rules (Karsenty et al. 1997).

Customarily, according to the "right of axe," the first clearing of forest conveys permanent use rights to a kin group and its descendents (Diaw 1997, Vermeulen and Karsenty 2001). As a consequence, almost no unclaimed land remains in the HFZ (Karsenty et al. 1997), since all the forest land marked in the pre-colonial time, for various uses such as cropping, temporary settlement, hunting, or fishing, are the objects of customary permanent claims by local people.

A gradient of access rules defines the use of forest resources by the different kin groups in a location. Forest land can belong to a lineage or a clan exerting exclusive rights, it can be partially open to other groups for short-term uses, or it can be a common area for open access forest use (ALR). Within this system, temporary individual rights are sub- sumed into long-term collective rights at different scales of management. Households exert short-term exclusive control on the land they crop, which is part of the land controlled by their kin group. For land left fallow, the progressive re-conversion into secondary forest coincides with individual control merging into the collective rights of the kin group.

In 1974, this system of land access was officially abolished and all the land was nationalized. Since 1994, forest use and management have been governed under the Forestry Law and the government has used a series of land allocation models and concessions to manage the state's forests. The Forestry Law of 1994 allocates forest into one of two domains, either permanent (PFD) or non-permanent forest (NPFD). The PFD covers $30 \%$ of the national territory and is designated to remain as forest (mainly production forests) for the long term. The NPFD may be converted to non-forest land and covers the remaining 5 Mha of forest in the HFZ . The law mostly excludes the local population from the control and management of forest resources. The exceptions are community forest concessions within the NPFD, which may be up to 5000 ha and include agricultural land.

\section{Material and Methods \\ Study site}

The study was conducted in the area of Akok (560 m a.s.l) located at coordinates N 2.74350 and E 11.23288 in southern Cameroon. The territory covers an area of about 11500 ha and is a fine-grained mosaic of land cover units that includes crop fields, cocoa fields, fallows of various ages, secondary forest derived from fallows, and remnants of the original vegetation. Forest cover is $82.4 \%$ of the area (Robiglio 2005).

All the territory falls within the NPFD (see Cote' 1992) and can be exploited by the local people through the institution of community forests or subjected to cutting permits for external industrial and small-scale loggers.

The area is sparsely populated — population density averages about $7 \mathrm{~km}^{2}$ — with most people living in hamlets along the main track. The people are Bulu, a Fang sub-group of the Bantu (Dugast 1949, Santoir 1995, Diaw 1997).

Kin groups living in the area belong to four different clans: Yemvan, Esala'ane, Yemissem and Yemekak. The Yemvan and Esala'ane were the first to arrive and occupied the present territory around the end of $19^{\text {th }}$ century, followed by Yemissem and Yemekak who arrived at the beginning of the $20^{\text {th }}$ (Mala et al. in preparation). The present settlement configuration of six villages is the result of internal conflicts and alliances among these groups: four villages have inhabitants from a single clan, and the remaining two villages contain members from a mix of clans (Fig. 1).

\section{The village level GIS}

A GIS database was implemented for spatial modelling purposes (Legg 2003), integrating satellite images with various sources of digital information at the regional and local level. At the local level, component features were: 1) land cover maps (scale 1:20 000), derived from Ikonos very high-resolution images, 2) household locations from GPS records, and 3) local transport network (including logging tracks) from GPS records. We used "expert" information on land cover as an interface between the spatial database and local knowledge. 


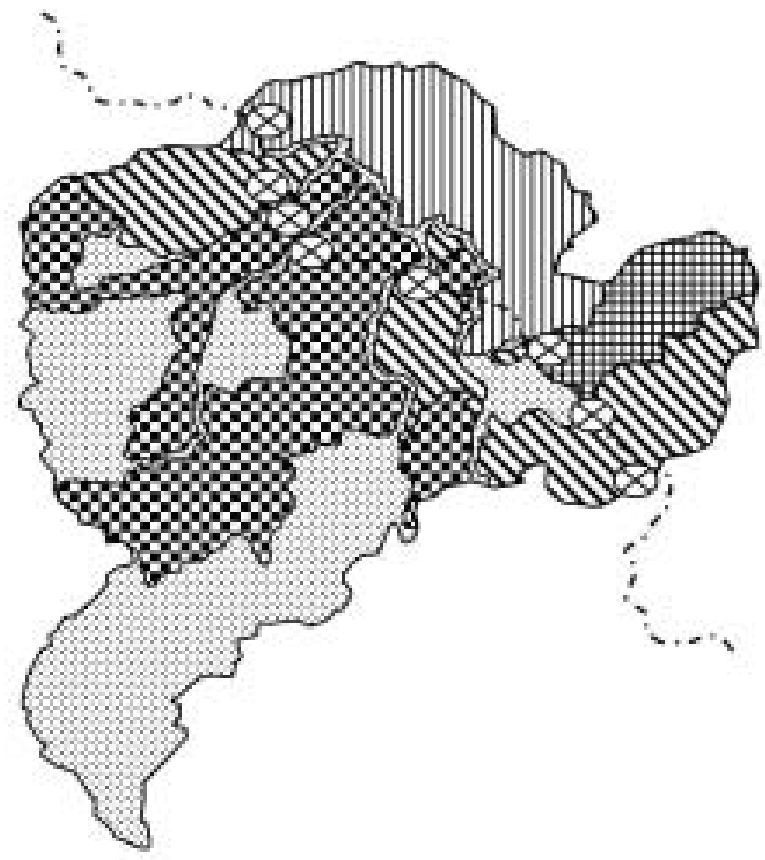

\section{Clan Territories}

Open Access Forest

W Yemekak

\#曲 Yemissem

IIIII Esala'ane

Q. Yemvan

$\otimes$ Main Settlements

- Main Track

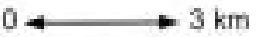

Fig. 1. Land associated with clan territories within the Akok territory

\section{Converting local knowledge into spatial attributes}

Local knowledge is the knowledge system resulting from the experiences, needs and observations of local people on the ecological conditions and environmental relations in a specific locality. It is presented as embodying many attributes and qualities (...) including reference to broad environmental and ecological contexts and dynamics, to cultural belief and social institutional systems.

(DAVIS AND WAGNER 2003).

In order to be integrated into a GIS structured on discrete geographical objects, local knowledge has to be organized as a series of attributes for spatial units. The landscape system approach provides the conceptual framework for defining spatial units that can carry biophysical and socio-cultural attributes. An essential element is a scale-sensitive insight that allows for equivalency between socially and biophysically defined levels of assessment to be established. The landscape is then defined as a nested system of spatial units according to criteria that make these units relevant to the questions being asked (O'Neill et al. 1989, Farina 2001). In our study, we took land cover as the basic attribute for defining landscape units. Local information layers were then "imported." Prior to importing the local information, a correspondence was established between land cover classes from the remote sensingderived land cover maps and the local classification of vegetation units. The rationale for this step was that the local classification maintains an intrinsic linkage between land cover and land use describing vegetation using land use related classi-
Table 1. Scale equivalence between land cover / land use classes and social units

\begin{tabular}{ll}
\hline Land cover/ Land use & Social units \\
\hline Field & Household \\
Fallow matrix & Lineage \\
Forest matrix & Larger kin group \\
Watershed district & Village community \\
\hline
\end{tabular}

fiers. From descriptions of the customary tenure system, we knew that the range of spatial scales covered by a land use type corresponded with identified levels of social organization. This allowed us to establish an equivalence scale between land cover/land use and social units (see Table 1).

\section{Data collection and analysis}

Data collection was organized in two phases: 1) the collection of the geographic information relevant for the community and the production of a geo-referenced base map, and 2) the collection of geo-referenced thematic information.

Relevant geographic references to be positioned with a GPS were selected by the community during the participatory mapping exercise. An accurate geo-referenced base map was necessary for enabling the integration of the information in the GIS and developing a consistent and shared reference space in the thematic discussions with the community groups.

Thematic layers are specific overlays sketched by a focus group, using transparent sheets superimposed on the base 


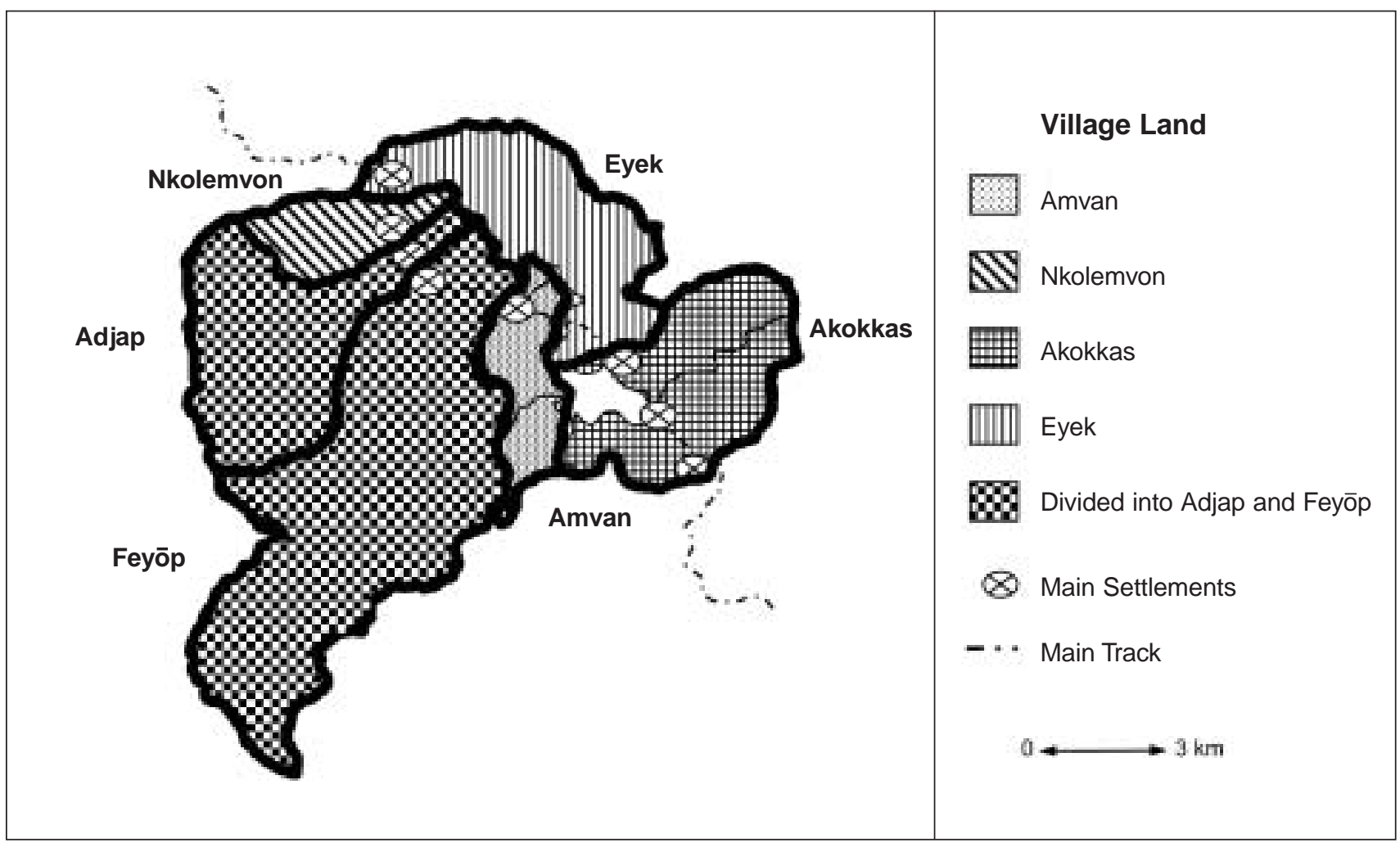

Fig. 2. Village borders associated with administrative units.

map. We defined the thematic structure, type and number of layers by analysing the original participatory sketches from the notes taken during the village meetings and the guided walks. On the basis of the equivalence scale in Table 1, we were able to collect land tenure data at a spatial resolution corresponding to the scale of management. Land cover map units were used as the elementary objects of reference for GIS data entry.

The thematic data collection was done in a series of meetings with identified focus groups. Four themes were mapped: 1) land cover/land use according to local classification of landscape units; 2) land access by clan, by lineage, by "big family"; 3) hunting rights, type, areas, types of animals, and abundance; and 4) fishing rights, type along river reaches, and fish abundance by watercourse reach. Some of the land cover units corresponded to single polygons (e.g., the forest corresponding to pure classes in the existing GIS land cover legend) and others to patches within a mixed mosaic, classified according to the building units (matrix of fallows with scattered cultivated fields corresponding to mixed classes in the GIS legend). In order to maintain the correspondence between type of unit and type of access, land access was sketched using the land cover/land use unit as a reference.

Data were then entered in the GIS and basic spatial analysis was done in ArcView 3.2. This included calculation of surfaces, cost-distance analysis, and analysis of population density or of land use intensity.

\section{Results and Discussion}

We found kin groups to be adequate units of observation for analysing the spatial arrangement of natural resource man- agement practices in villages and community lands. In Akok, where administrative borders do not correspond with kin group borders and the land of one group can exceed village borders (See Fig. 1 and 2), clan-level and village-level data were complementary in the analysis of population density pressures on forest resources (Table 2) and the interpretation of land use dynamics. This is particularly appropriate since clan land borders provide the context for household and lineage-level land use decision and land occupation strategies. Strong imbalances were found to exist among the clans when the land area, population density and population size were analysed in relation to the pressure on forest resources (see Fig. 3).

Within a village territory, the spatial structure of access rights creates a complex mosaic of land use units. Different agricultural and forest fragmentation patterns occur over short distances as the result of individual and collective strategies.

In Akok, lineage and household-level resource management and land occupation strategies are achieved through land use choices at the plot level. These choices are influenced by the ratio and amount of different vegetation cover types within the spatial frame resulting from the social arrangement described. Strong imbalances were found to exist in the amount and type of land area allocated within groups, with some lineages and families having little forest and large areas of fallow land. Surprisingly, these families belong to kin groups that have relatively rich forest resources within the clan's territory (e.g., the Yemekak) (see Fig. 1). This contradiction can be explained by the fact that these groups reside in small villages where population pressure is relatively high (e.g., Nkolemvon) (see Table 2) and their clan forest land 
Table 2. Land area and population density per village and clan lands; * is the population density value when the open access areas (ALRs) that fall in the two Yemvan mono-clanic villages (Akok-Feyop and Adjap) are considered Yemvan land.

\begin{tabular}{|c|c|c|c|c|c|c|}
\hline Villages & $\begin{array}{c}\text { Land Area } \\
\text { (ha) }\end{array}$ & $\begin{array}{c}\text { Population } \\
\text { density } \\
\left(\mathrm{km}^{2}\right)\end{array}$ & Clan & $\begin{array}{l}\text { Land area } \\
\text { (ha) }\end{array}$ & $\begin{array}{c}\text { Population } \\
\quad(2001)\end{array}$ & $\begin{array}{c}\text { Population } \\
\text { density } \\
\left(\mathrm{km}^{2}{ }^{2}\right)\end{array}$ \\
\hline Eyek & 1801 & 6 & Yemissem & 666 & 32 & 4 \\
\hline Akok-Feyop & 4331 & 7 & Esalane & 1815 & 142 & 7 \\
\hline Adjap & 1955 & 9 & Yemvan & 3441 & 426 & 15 \\
\hline Akokass & 1891 & 10 & Yemekak & 2182 & 521 & 19 \\
\hline Amvam & 821 & 18 & Yemvan +ALRs & 6641 & 426 & $7^{\star}$ \\
\hline Nkolmvon & 697 & 21 & & & & \\
\hline
\end{tabular}

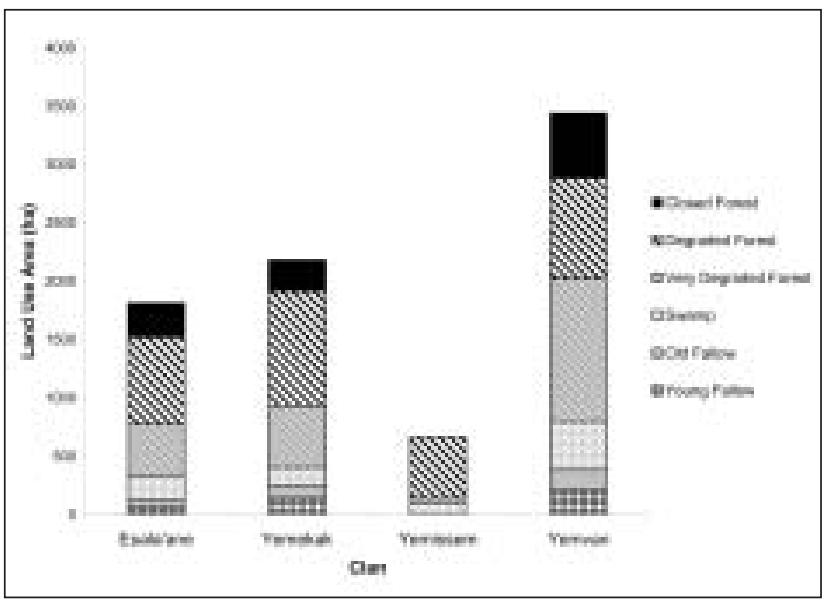

Fig. 3. Land use types by clan territory (does not include open access forest].

beyond the village boundaries is far away (around $10 \mathrm{~km}$ ) and already claimed by other groups. The pressure on land resources is thus discontinuous in space and is characterized by different gradients of land use intensity and forest fragmentation.

In all the villages within the region, two spatial foci can be distinguished: 1) the land around present settlements, which includes home gardens, agricultural short-fallow land and cocoa agro-forests; and b) the land around abandoned settlement sites in the forest, which includes cocoa agro-forests, forest-farms and long-fallow land. Within a $2-\mathrm{km}$ radius of a settlement, shifting cultivation is used for food crop production in a rotational system that alternates between agricultural fields and fallows of different ages. This land use strategy occupies $7-10 \%$ of the village's land within the $2-\mathrm{km}$ radius. At present, expansion of farms into forested land occurs on less than $1 \%$ of the village's total land area. Clearing forest land to create openings for forest-farms on long-fallow land, or to expand existing cocoa plantations, is typically part of the management strategy of individual households. However, in dense forest areas, forest-farms are often clustered, with farmers of the same family and lineage collaborating to fell and clear land within the clan territory and in the open access forest areas (ALRs).

The control of open access forest areas (ALRs) is crucial for defining future options for forest management and con- servation. Open access areas are used as common resource areas, open to any member of any kin group. In the Akok territory, $60 \%$ of the closed dense forest falls within the ALRs that occupy one-third of the whole territory (See Figure 1). These ALRs are generally used for hunting, fishing and harvesting NTFPs. However, 94\% (3200 ha) of the ALRs are located relatively close $(\sim 7 \mathrm{~km})$ to the main track and could be deemed suitable for agriculture or timber exploitation under the Forestry Law of 1994. Although the Yemvan — the earliest occupants of the area - tend to exert a sort of preemptive right on the ALRs, this is a controversial issue. The implementation of long-term management options within the ALRs has been hindered by institutional fragmentation that has promoted short-term individual strategies for resource use.

The use of participatory mapping was found to be an effective tool for explicitly defining resource management issues across the Akok landscape. This technique mobilised in-depth community participation and provided insights into the ways that different clan groups think and reason about natural resource management. However, this method involves a high level of expertise and techniques that can be expensive and are not always available at the local-level. Since the communities were excluded from the more technical aspects of the GIS implementation and management, the use of the spatial database was mostly extractive and only partially contributed to real empowerment of the communities in the case study area.

\section{Conclusions}

Although there is a marked contrast between a participatory approach to mapping natural resources based on local knowledge and experience and a purely technocratic one, the Akok case study demonstrates the possible complementarities of these tools and the added value of their integration. Once differences in data formats, data capture and modelling techniques were taken into account, it was possible to integrate these tools to work together. The result is a much richer analysis than would have been achieved with either tool alone.

Our study highlights the importance of understanding agricultural and tenure dynamics when implementing any strategy for forest management. In Akok, as in many other contexts, the agricultural and forest components are closely integrated and can not be separated within the definition of forest management. The analysis conducted in Akok also 
helps clarify the contradiction between collective and individual strategies in natural resource management at various scales of management.

Methodologically, the landscape system approach has demonstrated that it is an appropriate method for linking participatory methods with spatial analysis in GIS. Merging these two fields provides a platform for integrating forestry and agronomic research and enables research to be scaled up, both from the plot to the landscape level and from the household to the community level.

\section{References}

Coté, S. 1992. Plan de zonage. Cas du Cameroun, zone forestière méridionale. Objectifs, méthodologie, Plan de Zonage préliminaire. Ministère de l'Environnement et des Forets (MINEF). Cameroun. Davis, A., and J.R. Wagner. 2003. Who knows? On the importance of identifying experts when researching local ecological knowledge. Human Ecology 31: 463-489.

Diaw, M.C. 1997. Si, Nda Bot and Ayong: Shifting Cultivation, Land Use Property Rights in the South of Cameroon. Network Paper 21e, ODI Rural Development Forestry Network, London.

Dugast, I., 1949. Inventaire ethnique du Sud Cameroun. IFAN Dakar.

FAO. 2001. Global Forest Resource Assessment 2000. Main Report. FAO Forestry Paper No. 140 FAO. Rome.

Farina, A. 2001. Ecologia del paesaggio: principi, metodi, e applicazioni. UTET, Torino, Italy.

Geist, H.J. and E.F. Lambin. 2002. Proximate causes and underlying driving forces of tropical deforestation. Bioscience 52 (2): 143 -50.

Gockowski, J., J. Tonye, D. Baker, S. Weise, M. Ndoumbe, T. TikiManga and A. Fouaguegue, 2002. Characterization and diagnostic of farming systems in the ASB Forest Margins Benchmark of southern Cameroon. Research Monograph, International Institute of Tropical Agriculture, Yaounde', Cameroon.

Karsenty, A., L. Mendouga Mebenga and L. Penelon. 1997. Spécialisation des espaces ou gestion intégrées des massif forestier? L'exemple de l'Est Cameroun. Bois et Forêt des Tropiques. 251.
La Porte, N., C.O. Justice and J. Kendall. 1995. Mapping the dense humid forest of Cameroon and Zaire using AVHRR satellite data. International Journal of Remote Sensing 1 (6).

Legg, C. 2003. CamFlores: a Flores-type model for the Humid Forest Margin in Southern Cameroon. Small-scale Forest Management, Economics and Policy 2: 211-223.

Mala, W., V. Robiglio and M.C. Diaw. In preparation. Rural Settlements and Dynamics of Landscape Management Options in Southern Cameroon: Implications for Agroecological Sustainability. Mertens, B. and E.F. Lambin. 1997. Spatial modelling of deforestation in southern Cameroon. Applied Geography 17: 143-162.

Mertens B. and E.F. Lambin. 2000. Land cover change trajectories in the South of Cameroon. Ann. Assoc. Am. Geog: 90 (3): 467-494.

Ndoye, O. and D. Kaimowitz. 2000. Macro-economics, market and the humid forest of Cameroon, 1967-1997. The Journal of Modern African Studies. 38: 225-253.

Nounamo, L. and M. Yemefack. 2001. Farming systems in the evergreen forest of southern Cameroon : shifting cultivation and soil degradation. Tropenbos Cameroon Documents 8, Kribi, Cameroon.

O’Neill, R.V., A.R. Johnson and A.W. King. 1989. A hierarchical framework for the analysis of scale. Landscape Ecology 3: 193-205.

Robiglio, V. 2005. Impact of shifting cultivation on forest cover and vegetation dynamics in the humid forest of the South of Cameroon. In preparation for the IUFRO World Congress Session n.135 Detecting Monitoring and modelling deforestation and forest degradation using Remote Sensing and GIS.

Russel, D. 1993. Resource Management Strategies in the Central African Forest Zone. A handbook for IITA's Humid Forest Station, Yaoundé, Cameroon.

Santoir, C. 1995. Les groupes socio-culturels. In C. Santoir et A. Bopda (coordinateurs). Atlas régional Sud-Cameroun, MINREST/ Institut National de Cartographie. ORSTOM Edition, Paris.

Vermeulen, C. and A. Karsenty. 2001. Place et légitimité des terroirs villageois dans la conservation. In W. Delvingt. La forêt des hommes : Terroirs villageois en forêt tropicale africaine. Les presses agronomiques de Gembloux, Belgique. 